\title{
Framing Religion in a Transnational Space
}

\author{
Migration, Development Cooperation, and Faith Solidarity \\ between the Gulf and Pakistan
}

\begin{abstract}
This chapter examines the role of religion in a transnational space, shaped mainly by migrant and development actors between the region of Baltistan, in north-eastern Pakistan, and Kuwait. Migration from Baltistan to the Gulf, and to Kuwait in particular, is strongly connected to a specific socioeconomic context determined by the existence of the Kashmir dispute, but also to a shared religious belonging to the Twelver Shia faith of Islam. Development aid from Kuwait in north-eastern Pakistan is framed in socio-economic terms and in terms of the religious duty in Islam to share and distribute wealth, although this charity activity does not require that the recipients follow the same faith. By addressing the understanding of the religious among actors involved in this transnational space, such as migrants, employees, and donors of economic aid, the chapter discusses the interrelations between the religious and the political (as the realm of the public sphere) in the context of this transnational space. While noting that religion helps to structure specific collectives beyond existing sovereign borders and therefore has an ordering character that amounts to a political dimension, the understanding of the religious in transnational spaces cannot be divorced from existing power hierarchies in which religion is inscribed.
\end{abstract}

\section{Introduction}

Social scientists working on religion have long debated the methodological relevance of providing a definition of the concept. This discussion becomes even more entangled if we consider the role of religion in politics, as politics deals with religion as part of the social field, while religion is understood by believers as all-encompassing. On the one hand, the political use of the religious situates religion within specific boundaries or a sphere, a way of reassigning the meaning of the religious. On the other hand, believers and political scientists alike agree on the immanent character of religion, even though they may differ in distinguishing the manifestations of the religious. These considerations make it difficult to agree on a conceptualisation of religion in the field of inter- 
national politics which is relevant for the study of transnational spaces. Although religion 'orders' (the community of believers, international religious organisations, etc.), religion is not per se an order separate from politics, and in an ideal type religion requires enforcement at the social level.

Social scientists who focus on religion in the field of sociology and political science are perspectivists, that is, researchers who rely on observations (manifestations) of religions and their influence in politics. ${ }^{1}$ This approach invariably raises both the question of from where these observations are made and the debate about religion versus secularisation/post-secularisation. As Bader reminds us in his critique of Habermas' post-secularisation thesis, there are no completely secularised states or societies, and religion "is not generally subjectivised or privatised, and the state and (organised) religions are not strictly separated." ${ }^{2}$ In this respect, Bader relates the study of religion in the post-secular context to a debate about liberal-democratic constitutionalism and this approach is strongly shaped by the experience of the development of the Western European state. The question remains if the same can be said of the differentiated trajectories of the Global South.

In order to address this question, I discuss the role of religion in the making of transnational spaces as a way to study international politics, and I do so by analysing a case of transnationalism between Kuwait and Pakistan. Specifically, I explore the role of religion in what I call a migration and development network between Kuwait and Baltistan, an autonomous territory in north-eastern Pakistan. Baltistan is one of the two administrative divisions of Gilgit-Baltistan and the most homogeneous in terms of language, Balti, and religion, with the prevalence of Twelver Shia Islam. For the analysis of the role of religion, I consider this network within the broader transnational interactions between South Asia and the Gulf. This network is characterised by the reciprocal relationship between migrants from the Baltistan region working in Kuwait, members of the Kuwaiti merchant class supporting development projects in Baltistan, and religious leaders from Baltistan strengthening their position as power brokers in the political context of Baltistan through their involvement in educational work and as a result of their preaching and fundraising activities in the Gulf. Religion is initially conceived in terms of belonging to the same faith, since the majority of the members of this network adhere to the Twelver Shia sect of Islam, although the meaning of the religious is redefined through practice. I examine the role of religion in terms of its non-territorial character and based on the assump-

1 Bader 2012, 6-11, Luhmann 2000, Owen 2000, 173, Haynes 2016.

2 Bader 2012, 13. 
tion that religions contain worldviews about the organisation of social life on earth. Through existing religious structures and organisations, religious actors (leaders and the community of believers) work to influence world society in specific ways, and in most the cases this has political consequences.

Part of the problem in grasping the religious lies in the gap between topdown approaches, that is, between an organised (or recognised) religious system and the existence in society of a wide array of actors who also have their own assumptions about the religious and may display them for specific purposes. In this sense, Schwarz and Lynch propose to examine religion as practice in order to challenge fixed, historicised categories of the religious. ${ }^{3}$ This exercise implies considering the religious dimension as an attempt to incorporate the insider-orientated endeavour into social analysis in order to understand the reality of a particular worldview. ${ }^{4}$ Bottom-up approaches must therefore be included, but they should be contextualised by the structures in which actors operate and the deterritorialised element of religion vis-à-vis the territorialised nation state.

The chapter is structured as follows. It begins with some general considerations on the role religion plays via historical and migration processes between South Asia and the Gulf, exploring the relationship between the religious and the political (the realm of the public sphere). Then the second section moves within the general context of Pakistani migration to the Gulf, to describe migration from north-eastern Pakistan to Kuwait and how it is intertwined with the activities of religious actors with transnational links with the Gulf. Finally, the last section addresses the religious dimension of Kuwaiti development cooperation in north-eastern Pakistan as understood by donors and migrants. By exploring the meanings of the religious in this migrant and development network, I advance some considerations about the role of the religious in these transnational spaces and the potential overlapping of the religious with the political. This study is based on fieldwork carried out in Baltistan (north-eastern Pakistan) and Kuwait in 2017, 2018, and 2019 for a total period of about three months. Fieldwork activities consisted of interviews and participation in some activities involving this migrant community.

3 Schwarz and Lynch 2016.

4 Sheikh 2015, 136. 


\section{The religious and the political in the transnational context of South Asia and the Gulf}

Contemporary political developments in the Gulf region and in South Asia attach great importance to religious identity politics because of the mobilisation of actors who claim themselves to act on behalf of religion or according to religious principles, and due to state politics who directly or indirectly interfere with the religious sphere. This is the case of the Shia-Sunni sectarian differentiation in the Gulf region, which is represented in the state version as a matter of rivalry politics between Iran and Saudi Arabia. In South Asia, the developments in state politics play a major role. In India, the recent Citizenship Amendment bill of December 2019 questions the basis of Indian secularism because it clearly discriminates Muslims' access to citizenship. While scholars working in the field of international politics recognise the increasing importance of religion in influencing world affairs, they admit the difficulties of thinking about religious worldviews or, for that matter, approaching religion as an object of inquiry. ${ }^{5}$ The question is: What are we referring to when we discuss the role of religion in international politics? This is particularly true if, as Halliday observed, we assume that religious actors have not proposed any new form of political space and they normally, as the case of Iran illustrates, operate within the framework of existing institutions. ${ }^{6}$

The political use of the religious has received more attention in the study of political developments outside the most-developed parts of the world (with a few notable exceptions), while the question of the immanent character of religion has invited less scholarly reflection - except for the cases of India, which embraced its own version of secularism after decolonisation (religious pluralism in a religiously neutral state), China, and a few others. The immanent character of religion has often been regarded as a matter of degree, that is, in terms of how much/less religious a given society is, and what a 'good religion' is. Cesari, for example, considers 'civil Islam,' a concept she borrows from Robert Hefner, but one that she uses to indicate "the common reference for the public expression of all citizens under the same political rule". ${ }^{7}$ She analyses 'civil Islam' in the Muslim majority societies of Indonesia and Senegal (each of them with different

5 Hurd 2004, Fox and Sandler 2004, 2-3.

6 Halliday 2000, 131-41. The Taliban in Afghanistan could also be added to this.

7 Cesari 2018, 110. 
articulations of national identity) as a framework for a wide range of freedoms. ${ }^{8}$ She refers to 'civil Islam' as articulations of Islam that are based on social organisations that interact with state institutions as part of a consensual political culture, which is, in my opinion, connected with the functioning of liberal democracy. ${ }^{9}$

In order to examine what counts as religious in the transnational space formed by migrant and development actors between the Gulf and South Asia, I consider the actors who engage in activities deemed religious - such as education, preaching, performing rituals, fundraising for socially religious oriented purposes - as Sheikh pointed out, ${ }^{10}$ but I also problematise the boundaries of religion. It is important to understand genealogical issues (why a believer follows a specific religious leader or tradition and whether a believer hails from a certain religious family), how they are acknowledged by the actors participating in these networks, and the motivations of these actors. The boundaries of religion are analysed through the actors' own understanding of the subject and through their activities.

An analysis of the role of religion in transnational spaces appears, in the first place, determined by two apparently contradicting issues: the deterritorialised character of religion as a system of beliefs and communication (religion has no borders), and its localised manifestations that tend to coincide with existing state boundaries (in the sense of an identification of Iran as a Shia majoritarian state, or Pakistan and Saudi Arabia as Sunni majoritarian states and their acting with a religious dimension in international politics). Religious transnational actors such as political parties, whether in Europe, the Middle East, or South Asia, maintain transnational synergies inherent to universalistic values, but at the same time their focus and agendas remain within the boundaries of the states in which they operate. ${ }^{11}$ Although religion shapes transnational spaces, it cannot be said that these spaces are homogenous or primarily religious, as they are strongly embedded in the realities of a given regional, state, or local context. Moreover, they are also an expression of globalisation processes. ${ }^{12}$ In her work on Shia transnational networks, Laurence Louër recognises how initially deterritorialised actors, such as representatives of Shia Islam, have come to terms

8 Cesari 2018, 109-40.

9 Ibid., 125-26.

10 Sheikh 2015.

11 Perhaps one of the few exceptions to this is the Jamaat-e-Islami of Jammu and Kashmir, which defends the region on the Indian side to be merged with Pakistan.

12 Reetz 2013. 
with the politics of the nation state, while at the same time taking on a globalised character. ${ }^{13}$

Islam plays an important role in ongoing processes of transnationalisation between the Gulf and South Asia. The Gulf has influenced religious life in the Indian subcontinent for centuries, and South Asia has been home to revivalist movements that have expanded elsewhere, including to the Gulf. ${ }^{14}$ Islam spreads through the activities of organised religious actors, through the actions of individuals shaped by specific life trajectories, and through economic relations (such as trade in the past and migration in the present). By crossing state boundaries, Islam becomes the object of agendas at various levels (governmental, regional, local) in a process that may lead to transformations in society. Islam travels, but also often experiences a process of adaptation to the local context, that is, it also becomes localised. ${ }^{15}$

The Gulf remains the territorial epicentre of Islamic traditions. However, for decades, political scientists dealing with social mobilisation have not considered religion to play a central role in major political developments, except in the Iranian revolution. ${ }^{16}$ After the invasion of Iraq and the toppling of Saddam Hussein's regime in 2003 there came a turning point in the consideration of the religious question. Although preserving its territorial integrity, but not a sovereign state anymore, the power vacuum in Iraq was filled with a mobilisation of religious groups with diverse agendas. In particular, the previously oppressed Shia majority rose up, mobilised by religious clerics, and characterised by factionalism. More broadly, religious movements preoccupied with the renewal or purification of Islam have become important political actors, which in turn reinforce sectarian belonging. These developments have caused scholars working on the Gulf to increasingly examine the region through the lens of sectarian divisions between Sunni and Shia and the role of the petro-monarchies in funding religious movements elsewhere. ${ }^{17}$ Religion in this sense is tantamount to identity, as a factor of mobilisation for purposes that can sometimes be oppositional, and for addressing existing oppressions. For example, it is used to advance claims for justice for religious minorities, i.e. the Shia in Saudi Arabia, but also as an instrument of autocratic rulers to undermine political demands

13 Louër 2011, 297-98.

14 Gupta 2017, Ahmad 2017.

15 Green 2011.

16 Halliday 1988, 31-63, Skocpol 1994, 247-50.

17 Matthiesen 2013. 
for justice, as in the case of the ruling monarchy in Bahrain against the demands for rights by the Shia majority population.

Muslim majority societies in the Gulf do not necessarily mobilise along religious lines, although there are groups with specific religious agendas that took part in the mobilisations connected to the 'Arab spring'. Furthermore, Gulf monarchies do not follow an explicitly theocratic agenda, neither in their domestic nor in their foreign policy. Saudi-Iranian rivalry, for example, has an important religious dimension in terms of competing for a hegemonic religion (Sunni vs Shia Islam) that is no different from other ideological movements and often confronts the realities of religiously plural societies. Gulf monarchies do not act differently from other dominant actors in the state system: while they agree with the principle of state sovereignty and the sanctity of state boundaries at home, they try to exert influence elsewhere, often ignoring the principle of territorial integrity, as illustrated by the case of Saudi Arabia's intervention in Yemen.

Like any other religion, Islam is thus inclusive of the community of believers, but as a political project, Islam will always encounter the problem of Muslims who belong to the faith but on unequal terms, e.g. because of being cultural minorities, deprived social groups, or individuals who make new demands on the community, etc. This is similar to Rancière's understanding of politics as la part sans part (2009), that helps to reconfigure the relationship between the religious and the political in the sense that religious subjects, considered as non-political subjects, become political agents when they make claims in the public sphere. ${ }^{18}$

The former can be exemplified in the case studied for purposes of analysis, and can be termed a transnational Shia space. Participants in the development and migrant network between north-eastern Pakistan and the Gulf belong to this faith and operate following channels connected to Shia groups and organisations. However, this labelling does not imply that there is a specific political aim connected to this religious dimension. Migrants from north-eastern Pakistan travel to the Gulf in search of work and the prospects of improving their life conditions, and whilst they certainly prefer to work for families or companies of the same faith, some of them commented in interviews that they would have preferred to go to Europe if they had the option. Religion per se is not a driving force for their activities, and they are often critical of Gulf regimes who treat them as foreigners, and often discriminate them on the basis of their lower social status. Instead of feelings of attachment due to shared religious faith, the

18 Morrison 2013, 899. 
Gulf experience is often framed in critical terms. However, on the whole, the activities of these transnational networks have a political impact because some actors gain power and influence with the reorganisation of social boundaries (i.e. empowering Shia communities in north-eastern Pakistan or empowering Shia merchant classes in Kuwait). In other words, they become visible in the political system and their religious identity constitutes an important marker.

Religious ideas continue to flow via religiously motivated actors (ranging from individual students to organisations) pursuing religious agendas, but especially through migrants' experiences which depend very much on their own engagement with their homeland and with the receiving societies. ${ }^{19}$ This engagement can be motivated by integration or acquisition of knowledge in the host society, or by a sense of exclusion, reinforcing their beliefs about a perceived hostile environment in the host society. However, migrants' religious experiences as a distinct social group (those who have worked and lived abroad for a period of time) have, in general, limited possibilities to effect a radical change in the political system in their homeland regarding the religious orientation (for example, at the state level). They can certainly influence political agendas through their economic power or knowledge by supporting actors or groups with certain religious orientations. The same applies to religious transnational political parties, such as Jamaat-e-Islami, which are often involved in providing knowledge transfer for mobilisation purposes, charity work, and receive funding to develop their political agendas in a transnational context. In most of these cases, religion or the religious in transnational processes between South Asia and the Gulf functions as a reinforcement of existing transnational ties, as a non-territorial relationship that shapes collective identity - and also individual identity. This relationship structures socio-spatial relations (addresses inequalities, provides support, and promotes specific religiously-oriented actions) and creates specific geographies of knowledge, but has little influence on the international system.

19 Gupta 2017, Ahmad 2017. 


\section{Migration from Baltistan to Kuwait: Contextualising religion}

Different communities in present-day Pakistan have a long tradition of settlement in the Gulf that precedes the discovery of oil in the region, and the formation of the Pakistani state in $1947 .{ }^{20}$ However, the development of the oil industry and subsequent modernisation of the Gulf States after the 1930s triggered large-scale migration from what are today the territories of Pakistan. Pakistanis are at present among the largest migrant populations in many Gulf States. The Gulf functions as a destination for the excess labour unable to be absorbed into the Pakistani labour market. Pakistani migration is constituted mainly of unskilled or semiskilled workers, but there is also a significant presence of highly qualified professionals and technical expertise, attracted by competitive salaries. The boom in Pakistani migration to the Gulf occurred in the 1970s and 1980s during the governments of Zulfikar Ali Bhutto and Zia ul Haq. While both leaders saw migration as a source of remittances for the country and as a way to gain influence in the Gulf States, they adopted very different approaches. Bhutto favoured a policy of sending highly skilled workers (doctors and teachers) to countries such as Oman, while Zia ul Haq strengthened the military cooperation by sending military personnel and advisors to Saudi Arabia and the UAE.

It was under the rule of Zia ul Haq - who initiated the Islamisation policy of the state - that Gulf migration began to be associated with a religious overtone. This does not mean, however, that the Islamisation policy of Pakistan and the rise of religion in its institutions (especially that of the texts and traditions of the Sunni sect of Islam) is the result of a bottom-up transformation at the societal level; on the contrary, it was a top-down policy driven by geopolitical considerations. The triumph of the Shia revolution in Iran and the Pakistani collaboration with the US, to support the Afghan mujahideen against the pro-Soviet government in Kabul, were important factors that mobilised religion from above. ${ }^{21}$ In this broader context, migration channels were natural means through which migrants became socialised and familiarised with Gulf traditions. However, they were also channels employed by other actors (sometimes religiously motivated) with specific political agendas, such as the recruitment of mujahideen for the Afghan war, or the dissemination of more intolerant religious views.

20 Addleton 1992, 41-42.

21 Coll 2004, Siddiqa 2007. 
Pakistani migrants in the Gulf States are confronted with different varieties or interpretations of the Islamic tradition and these experiences affect their trajectories once they return to Pakistan. Sometimes they would adopt these traditions, inducing changes in their most immediate home contexts, at other times, they would remain unaffected (if not hostile) to these influences. The Arabian Peninsula, as the birthplace of Islam, plays a moral role for Pakistani Muslims, but migrants' religious views while working in the Gulf States are also moulded by their own immediate experiences and encounters, often characterised by open discrimination due to unequal social relations. During my research in Baltistan among migrants to the Gulf States, they often defined Gulf societies, and Saudi Arabia in particular, as being dominated by 'non-good Muslims'. They would relate this assessment to personal experiences of abuse, fraud, and a perceived lack of respect for other human beings in these wealthy societies.

\section{Characteristics of migration from Baltistan to Kuwait}

The transnational space - formed by migrant networks from Baltistan to $\mathrm{Ku}$ wait - is shaped by three main characteristics. First, the territory of GilgitBaltistan, to which Baltistan belongs, is part of the Kashmir dispute. Although migrants from this region are indistinguishable from other Pakistani migrants abroad - because they carry normal Pakistani passports - they are not full state citizens at home. This affects these migrants' strategies while abroad. Second, migrants from Baltistan operate mainly through strong personal networks that get them work permits, with links to the Gulf, and are therefore less reliant on the often abusive recruitment agencies. Third, the majority of these migrants belongs to the Twelver Shia faith of Islam (a minority in Pakistan but a majority in Gilgit-Baltistan), and religious marking seems to play a role in this migration channel; many migrants are employed by Shia families who, in the case of $\mathrm{Ku}$ wait, belong to the traditional merchant class and share nationalist values more than, for example, the more Islamist-militant views of the nouveau Shia riche. Thus, in order to understand this transnational space, we need to pay attention to the respective contexts that favour this transnational engagement, the personal element in the establishment of relations, and the role exercised by religion.

The legal status of Gilgit-Baltistan is linked to the Kashmir dispute, but the region is gradually being integrated into the Pakistani state. ${ }^{22}$ By 'being inte-

22 Mato Bouzas 2017. 
grated' we refer to the fact that the Pakistani executive and judicial powers enact decisions and laws that display sovereign competences over this territory. However, parts of the Pakistani Citizenship Act do not apply to Gilgit-Baltistan in full, and therefore there are important restrictions on the political and legal rights of people. Baltistan is the administrative division located in the south, bordering the Line of Control with Ladakh, India. The social landscape of GilgitBaltistan is culturally and linguistically diverse, partly due to it being a highmountain region with deep valleys, which has historically favoured isolation and privileged some channels of communication channels over others.

Being part of the Kashmir dispute determines many aspects of social life in Gilgit-Baltistan - political freedom, rights, development - but potential integration into the Pakistani state also raises some uncertainties in the society. The specifically Sunni, identitarian dimension of the Pakistani state is seen by some scholars as an obstacle to the incorporation a Shia-majority area. ${ }^{23}$ More recently, the viability of the China-Pakistan Economic Corridor - a megaproject that involves the creation of a large amount of infrastructure in Pakistan with China's support - has also added some real concerns due to its dramatic impacts on the local populations and its more general geopolitical implications. China has demanded that Pakistan integrate Gilgit-Baltistan in order to develop projects there, and Beijing is already providing services such as the internet. ${ }^{24}$ The Sino-Pakistani collaboration is a source of irritation to political and defence circles in India, who believe that China is actually in control of the territory.

In this context, migration from Baltistan to other parts of Pakistan and to the Gulf is strongly linked to the lack of economic opportunities associated with political uncertainties. The border with Ladakh is closed and communications with the rest of Pakistan are limited to a daily flight (subject to weather conditions), a wretched road to Islamabad, via Gilgit, and a seasonal road through the Deosai plain that connects the region during the summer. Although it is not accurate to say that Baltistan is a fully landlocked territory, it is certainly peripheral in terms of communications. The existence of the dispute favours investments (infrastructure) related to military needs, and the army occupies a large amount of land that could be used for other productive activities. Periodic cross-border skirmishes make it difficult for rural populations to tend their fields. Moreover, except for a few entrepreneurial agricultural initiatives supported by the Aga Khan Rural Support Programme (AKRSP), there are no possibilities to develop small industries, with the only exception of tourism. Indeed,

23 Shaikh 2009, 66-67, Stöber 2007, 407.

24 Dawn 2016. 
tourism has experienced a boom since 2014 and some migrants in the Gulf are investing in this sector. In sum, migration to the Gulf is determined by economic considerations connected to the political status of Gilgit-Baltistan. Significantly, the largest group of migrants from Baltistan in Kuwait are from the border areas near the Line of Control.

The second aforementioned characteristic of migration from Baltistan to the Gulf is its organisation around strong personal networks and the only occasional use by migrants of the riskier recruitment agencies. The origins of migration to Kuwait, which consists of some 1,400 adult males at the time of research in 2018 and 2019, can be traced to one man, Sheikh Hassan Mehdiabadi, a former religious student from Baltistan in Iraq who ended up in Kuwait in the 1970s. He left Iraq during Saddam Hussein's massive expulsion of Shias on the accusation of the latter being the fifth column of Iran. Once in Kuwait, he began to preach in the hussainiyas (Shiite congregation halls, mostly known in South Asia as imambargahs) about the condition of people in Baltistan and, through this activity, he met with influential members of the Kuwaiti Shia merchant class whilst raising funds for his own charity activities at home. He provided an account of the political situation of Baltistan to promote support for his fundraising, as members of these families still recall. Migrants who travelled to the Gulf state through the mediation of Sheikh Hassan, and whom I interviewed in February 2019, also identified Sheikh Hassan as a mediator who, in the context of his own charity activities, asked the Kuwaiti families to employ people from his home region. At present, other religious figures from Baltistan continue to be related to this migration network, although it is unclear if their activities are limited to religious and charity work or if they have a specific role in facilitating migration.

The importance of strong personal connections for migrants stems from their role in building stable and lasting connections between participants in a context characterised by the vulnerability of living abroad for the first time. These connections also serve to articulate a form of belonging to this transnational space, characterised by expectations of help and mutual support, but also by coercion, with the reputation of the community also resting on the individual's behaviour. Migrants from Baltistan are organised as an association in Kuwait. The association has rented rooms in the city, which are used for migrants' gatherings (and sometimes to perform prayers and minor religious services) and for short-term accommodation (when losing a job or before leaving the country). Each room, a total of seventeen in 2019, is used by migrants from a specific village or area and each member contributes to the rent (renting a room in Kuwait is extremely expensive). Large religious gatherings, such as the celebration of 
festivals like Muharram or other preaching activities, take place in the hussainiyas. Migrants also visit mosques for prayers. Shared religious belonging by migrants and by the Kuwaiti Shia community helps those migrants to gain access to the latter's resources, mosques, hussainiyas, and patronage. Not only the Shias from Baltistan benefit from this access; the entire migrant community from this region of Pakistan is positively affected. Access, however, does not mean access on equal terms. Migrants' access to praying in mosques and attending hussainiyas follows different time schedules from those of Kuwaitis. Although migrants have access to the same religious spaces as the national community, this access follows the existing segregation between citizens and non-citizens. Moreover, there are also elements of differentiation related to the structure of Shia Islam that are reproduced by migrant groups. Other community activities include the participation in the cricket league formed by migrants from Baltistan and Kargil, with eleven teams. The cricket league takes place on Fridays for several months and it is part of a larger urban landscape, formed by migrants from other South Asian countries who also play this sport in the open spaces in the city. In this context, as the head of the community mentioned to me, "it is impossible that there is a Balti in Kuwait whom we do not know."

A third aspect that determines this transnational space is its specifically religious dimension, which is exemplified by the role played by religious actors and the practices and activities of migrants in Kuwait. Although migration is the main (economic) activity, there are religious actors (students and sheikhs) who seem to play the role of middlemen owing to their privileged access to religious networks and the entrepreneurial class in the Gulf. These religious actors are part of transnational communities characterised by a high degree of social cohesion. ${ }^{25}$ Moreover, religious aspects are reinforced by a number of activities and connections. Many Shia migrants work in companies owned by wealthy Shia families, yet these families also employ Sunnis and Nurbaskshis (a minority group distinct from both Shia and Sunni) from Baltistan. Although migrants have access to the same religious spaces as the national community, this access follows the existing segregation between citizens and non-citizens. Moreover, there are also elements of differentiation related to the structure of Shia Islam that are reproduced by migrant groups.

25 Faist, Fauser, and Reisenauer 2013, 14-15. 


\section{Belonging to Shia Islam: The grand and the 'small' mullahs}

Shia Islam is organised around the structure of the marjaiyya (the supreme religious authority based in Iran and Iraq) and believers decide which marja or grand ayatollah to choose. Grand ayatollahs have their own doctrinal differences and one of these concerns the role of religion in politics. ${ }^{26}$ Khomeini's defence of an Islamic government (wilayat al-faqih) in the 1970s provoked a schism in the religious leadership because other grand ayatollahs, such as Abu al Qasim al-Khoei, and his successor Ali al-Sistani, did not share this view and adopted a more quietist position. ${ }^{27}$ Further differences have accentuated the fragmented religious landscape, which is characterised by strong competition between the followers of eminent, established religious figures and aspirants. Moreover, this religious landscape, which in principle has no definitive territorial basis, but which is connected to the context in Iran and Iraq, is fully transplanted to the microcosm of Kuwait. ${ }^{28}$

Migrants in Kuwait, in their condition as followers, become acquainted with this polarised religious context and some of them align with one group or the other. A few migrants I interviewed acknowledged at first that there were no differences between followers of one or another marja as all are Shia. However, during our conversations they would state their preferences to regularly attend certain mosques and identify themselves as belonging to a specific group, whether as 'Shirazis' (followers of the grand ayatollah Sadiq al-Shirazi, commonly known as Shiraziyyin) or as 'al-Sistani' (in reference to the grand ayatollah Ali al-Sistani), the latter being probably the most prominent group in Baltistan. In fact, these networks appear to be ordered according to these two marjaiyya. Migrants' positioning in this dynamic religious spectrum of Shia Islam depends on their established relations in Baltistan and seems to be unaffected by the religious scene in the Gulf or the wider spectrum of Shia Islam at large. This is the case of a migrant in his late fifties with whom I met up in 2018 and 2019 in Kuwait. He first moved to Kuwait in 1982 and travelled widely in the region (Iran and Iraq). He identified himself as a Shirazi and articulated his religious belonging in the following way:

Shirazi, Sistani, Khomeini... all of them are the same. All of them do good. Khomeini, now Khamenei, they do well in Iran but they are 'too much religious' [emphasis of the author].

26 Louër 2011, 76-79, Rizvi 2018.

27 Rizvi 2018, 175.

28 Louër 2011, 167-76. 
There are no differences. Some of them are more open than others. Iran is a developed state (...). In Baltistan some mullahs are very educated such as Sheikh Mohsin, Sheikh Jaffari [present imam of the Skardu great mosque, the capital and main city in Baltistan]; they have studied many years abroad in Iran and Iraq and they have seen the world. They are open-minded and they support female education. Other mullahs have no education and they do not know the world. These mullahs, I call them chhote mullah [small mullahs], studied a few years but they did not finish their studies. They just wear turbans but there is nothing in their heads. They are constantly saying to people, 'do not do this', 'do not do that'.

This man's understanding of religion as being a Shia can be related to a personal trajectory characterised by relative economic success and access to religious and economic circles in Kuwaiti society, as well as by his experience of having married a stateless woman in Kuwait - born in Iraq as the daughter of a former religious leader from Kargil who left before independence and never returned to this home area - and having children (of Pakistani nationality) raised in a consumerist and modern Gulf society. His views on religion in the context of Baltistan, also found in similar comments made by other migrants, were strongly connected to ideas of progress and modernity, implying a knowledge of broader societal transformations. Notably, he distinguished between those religious leaders in Baltistan educated abroad for many years (and part of broader networks) and those who were educated locally (or with limited international exposure). In any case, he attributed an influential role in guiding the predominantly rural society of Baltistan to those religious leaders with less education. He provided the example that while foreign-educated religious leaders were in favour of female advancement and did not oppose vaccination campaigns, 'small mullahs' did not share these views. Indeed, anti-polio vaccination campaigns in Baltistan and other parts of Pakistan have often raised suspicions among some religious leaders who consider them as a way to spread 'Western' diseases or sterilise the population.

A sense of shared religious belonging is important in this migrant network. This is an element openly acknowledged by migrants, who say that Kuwaiti families from the Shia merchant class are 'helping' them by providing them with jobs. Members of this merchant class, however, do not explicitly refer to a sense of religious shared belonging, but rather reference Islam to explain their commitment to philanthropic activities. ${ }^{29}$ Kuwaiti families see charity as part of the Islamic precept to share wealth with the less socially advantaged, irrespective of

29 Lacey and Benthall 2014. 
their creed..$^{30}$ Even so, for this Kuwaiti Shia merchant class, an influential minority in the country, the support provided for development activities in Baltistan in the fields of health and education is framed in non-religious, and certainly non-political, terms. The developmental activity carried out in Baltistan, which is articulated and publicised via local information panels on the spot, brochures, and videos, does not mention religion as a field of intervention. During an interview, members of the Marafie family referred to their contribution to the building of mosques, for example, and said that this was a personal contribution which was carried out by other NGOs and that they saw it as separate from their developmental work. To recapitulate, we could agree that the views of both the migrants and the Kuwaiti merchant class on the role of Islam in society contain specific values that can be described as political.

\section{Development assistance from Kuwait in Baltistan: International cooperation or faith solidarity?}

The Gulf has a philanthropic tradition of involving the engagement of prominent families from the merchant classes in foreign regions, with which they have traded for centuries. This developmental cooperation abroad is preceded by a tradition of charity work at home that favoured the modernisation of Gulf societies in fields such as health and education. ${ }^{31}$ As in the case of charitable activity from the global North, support for the needy by these actors from the Gulf, mainly in east Africa and South Asia, has often been shaped by religious values and combined with support for religious-specific interventions such as donations to build mosques, contributions to the activities of religious actors, and the boosting of religious education. ${ }^{32}$

Developmental work in Baltistan supported by Kuwaiti organisations and individuals is acknowledged, by these organisations themselves and by the migrants from Baltistan, as having both a religious and a not specifically religious dimension in the sense that both fields are identified as separate. These two descriptions are distinguished in ways that show the interplay of religion with modernity and with the question of the often-assumed sectarian identity. In March 2018 I had an interview with members of the Marafie Foundation,

30 Mato Bouzas 2018.

31 Crystal 1995, 25; 45.

32 Lacey and Benthall 2014, 1-4. 
which is an NGO funded along the lines of the previous philanthropic work by Mohammad Rafie Husain Marafie in Kuwait, an influential family from the country's traditional merchant class. The Marafie Foundation is at present run by the son and other descendants of the Marafie family, therefore it is a family foundation, and concentrates its developmental work abroad, mainly in Pakistan, but also in Iraq, India (the state of Kerala), and China, among other countries. ${ }^{33}$ During the interview, they mentioned that their decision to support developmental activity in Baltistan in mid-1987 was connected to their relationship with the preacher Sheikh Hassan Medhiabadi, and the fact that they had travelled to the region to assess the situation. Views about development held by the members of the Marafie expedition to Baltistan differed from those of the sheikh and the local people. In the interview, they spoke about their disagreement on funding a school only for boys and the strong opposition to female education in Baltistan at the time, something which they saw as 'backward'. They did not express this difference in religious terms, however; they only mentioned that the role of the religious leader in the community at the time was not in tune with what religious teachings - according to the religious community of Kuwait - would say about female education. The Marafie justified their disposition as a wealthy family to support the needy on the basis of religious duty (khoms and zakat). Religion in this case was thus understood as ethics, ${ }^{34}$ a relationship of the individual in the world as part of a specific context in which religious belonging was not at stake. ${ }^{35}$ In fact, the Marafie Foundation targets non-Muslims as well, although it is unclear how they select their projects. It seems that this developmental activity is strongly guided by existing personal acquaintances. As other merchant families, the Marafie also support religious specific interventions, such as the building and restructuring of mosques, but this is channelled through other charities and the Marafie Foundation is not involved in these specific actions.

The Marafie Foundation in Baltistan mainly deals with infrastructure schools, dispensaries, etc. - functioning alone or in partnership with the government of Pakistan (which provides, for example, the teachers and the material for the schools). The work of this NGO is different from the AKRSP, the largest NGO in the region, in scope and orientation. The Marafie Foundation is limited to the specific fields of health and education, and is only involved in providing infrastructure and specific actions, such as bringing doctors to operate in a

33 See www.marafiefoundation.org.

34 Lynch 2014.

35 On giving as an individual obligation, see Lowi 2017, 568-69. 
hospital in the summer, providing sums of money for families caring for orphan children, etc. It is too early to observe if their activities can be sustained over time because some more fieldwork is needed to understand the scope of their developmental activity. Compared to the AKRSP, which draws its employees from the regionally educated intelligentsia of Gilgit-Baltistan, the Marafie Foundation relies more on local networks in Baltistan, sometimes connected to specific families. In sum, the Marafie do not see their philanthropic activity as religiously oriented, although it is guided by religious principles, and they distinguish their religious specific interventions - which they support through outsourcing funds to other NGOs and through donations to religious actors from their non-religious developmental work.

Nevertheless, some migrants see the activities of the Marafie Foundation as having something to do with religion. A young semi-skilled worker in Kuwait, probably in his early thirties, described to me his plan to set up a small NGO in Baltistan with other migrant friends upon their return to the region. He explained very detailed aspects that showed his social commitment, unlike comments I had often heard from other migrants when I mentioned my interest in knowing about how migrants contribute to development. As there were already many NGOs in Baltistan, I asked him about the difference between his project and others at work, such as the Marafie Foundation. He answered: "We are not doing religion". On hearing this, I asked him to explain his words. Unlike the Marafie, he and his friends wanted to do 'small work', that is, to use petty money to help poor people to buy medicine, no matter what their religion was or where (which village) they came from in Baltistan. In his view, the Marafie Foundation had a religious orientation that favoured the Twelver Shia over other groups and, although he was himself part of that community, he said that the culture in Baltistan was 'different'. He claimed that, with his project, he wanted to support poor people, irrespective of their religious affiliation, because this was more reflective of society in Baltistan. Other migrants expressed similar opinions, underlining a gap between the apparently religiously-driven focus of developmental work and a home society that, in their view, does not need such a religious orientation, at least from the perspective of the low- to middle-income families to which the migrants belong.

The views mentioned during the interview with the Marafie family and this migrant (shared by a few other members of the community that I met with) show that there is no consensus on what is religious or non-religious in the transnational developmental field under study. There is, however, a shared perception, often implicit but other times explicit, that belonging to the same branch of Islam plays a crucial role in participation in this transnational space 
and can facilitate access to resources. At the same time, religion is perceived by those participating in this network as a quite organised affair, that is, as one that follows certain procedures - in fundraising and financial obligations - and that considers certain practices as universal. However, what is perceived as neutral in religious terms by some members of the network - such as the Marafie Foundation, the religious leaders, and a section of the migrant community - may not be shared by others, such as the migrant (himself a Shia) mentioned above. This differentiation shows, on the one hand, that when we investigate religion as an empirical object of research, we are implicitly limiting the scope of religion, a fact not shared by believers. On the other hand, we observe that members of these majority Muslim societies (in this case, the Shia majority society of north-eastern Baltistan) also place religion in a certain context or sphere. For the latter, religion can be connected to the activities of actors and organisations, as organised religion, but not necessarily extended to the rest of the society.

\section{The role of religion in transnational spaces: Some final considerations}

The analysis of the role of religion in the transnational space formed by migration and development networks from north-eastern Pakistan and Kuwait shows how the religious question is mainly framed in hegemonic terms (whose religion?). Despite sharing the same religious belonging, religion, when associated with developmental activities, is perceived by migrants from Baltistan as something external to their own religious (or for that matter, multi-religious) context. In other words, religion as a link to developmental activities is seen as introducing a differentiating character in that society. Religion in this sense can be seen as a form of spatial organisation that emerges from above (or from outside) and is distinct from existing forms of local organisation that are also seen as religious by the society. This understanding differs from the study of religion in post-secular (developed in economic terms) contexts, which, as Bader points out, should be framed as a debate about liberal-democratic constitutionalism. Assuming that Western developed societies have not been fully secularised, one can equally consider that other societies with a religious definition of the state have never been fully religious.

Although religion in this transnational space refers to 'organised religion', in the sense of a line of action in which religion grasps the all-encompassing 
field of the social, this does not mean, as some migrants asserted by questioning this religion 'from above', that religion should be placed in the sphere of the individual, in the sense of one's own behaviour and understanding of the world. On the contrary, migrants sense that their own religiosity does not lead them to categorise human beings by religion. In this context, religion amounts to a form of ethics. The role of religion in the context of Kuwait (and the Gulf in general) sponsored development activities in Baltistan is perceived as critical in an existing religiously plural society. In this view, religion, when associated with developmental activities, is acknowledged as essentially ordering because it (through developmental activities) redraws the boundaries of the religious community (Shia Islam). Although it is not possible to speak of the existence of religious pluralism in those societies, there are forms of social organisation that do not follow religious lines, and religion is sometimes understood in a more 'flexible' context than that described in many academic writings about these societies. In other words: What is understood as religious depends very much on how and which questions are being asked about the subject.

Members of the Kuwaiti merchant class who support development activities in Baltistan operate by following a sense of religious duty. They claim, at least in the case of the Marafie Foundation, that they do not discriminate on religious grounds while doing their development work. They fund non-religious, or religiously neutral, interventions (such as building a health clinic, bringing doctors to the region under medical campaigns), but they also support the religious and charity work of religious actors, such as the sheikhs. Through this development activity, the role of these religious actors as benefactors in Baltistan's society is reinforced. These interventions comply with the general regulations of the Government of Pakistan, which is an Islamic republic. While this support is perceived by the donors and recipients as a form of solidarity, outsiders to this network, as well as some migrants, maintain that this aid is linked to geopolitical issues.

Developmental cooperation generally has an altruistic element when it is not completely driven by political aims, but it certainly has political consequences most of the time. In the sectarianised spectrum of the Gulf, and in that of Pakistan, the fact that this transnational space is predominantly constituted by actors belonging to Shia Islam raises many questions about the very nature of its functioning. In Shia Islam, personal relations in a decentralised context play an important role through the marjaiyya system and these networks seem to be related to the al-Shirazi and al-Sistani groups. Religious actors have access to resources and, depending on this access, may become influential community leaders. Their role, however, is not limited to the religious sphere, because even 
when these actors advocate for the view that religion should not play a political role - as some trends in Shia Islam indicate - they are still making a political statement. Development and migration networks between north-eastern Pakistan and Kuwait thus share a 'Shia character' in the sense that ideas and practices of Shia Islam are part of this transnational space. Yet, these religious ideas and practices are not always easy to differentiate from a specific socioeconomic, political, or cultural context such as those of Kuwait and Baltistan. In other words, the role of the religious in transnational spaces cannot be understood without paying attention to the power hierarchies in which religion is inscribed. Religion can be seen as a form of solidarity by some of the participating actors, but also as something potentially divisive by others. 


\section{Bibliography}

Addleton, Jonathan S. 1992. Undermining the Centre: The Gulf Migration to Pakistan. Oxford and Karachi: Oxford University Press.

Ahmad, Attiya. 2017. Everyday Conversions. Islam, Domestic Work and South Asian Migrant Women in Kuwait. Durham: Duke University Press.

Bader, Veit. 2012. "Post-secularism or Liberal-Democratic Constitutionalism?" Erasmus Law Review 5, no. 1: 5-26.

Cesari, Joselyne. 2018. What is Political Islam? Boulder: Lynne Rienner Publishers.

Coll, Steve. 2004. Ghost Wars: The secret story of the CIA, Afghanistan, and bin Laden from the Soviet invasion to September 10, 2001. New York: Penguin Press.

Crystal, Jill. 1995. Oil and Politics in the Gulf. Rulers and Merchants in Qatar and Kuwait. Cambridge et al.: Cambridge University Press.

Dawn. 2016. "Pakistan mulls elevating status of Gilgit-Baltistan on Chinese insistence." January 7, 2016. https://www.dawn.com/news/1231394, accessed March 26, 2021.

Faist, Thomas, Margit Fauser, and Eveline Reisenauer. 2013. Transnational Migration. Cambridge: Polity Press.

Fox, Jonathan, and Shmuel Sandler. 2004. Bringing Religion into International Relations. New York: Palgrave Macmillan.

Green, Nile. 2011. Bombay Islam: The Religious Economy of the West Indian Ocean, 1840-1915. Cambridge et al.: Cambridge University Press.

Gupta, Radhika. 2017. "Seeking knowledge 'from the cradle to the grave': Shi'a networks of learning in India." In Pan-Islamic Connections. Transnational Networks between South Asia and the Gulf, edited by Christophe Jaffrelot, and Laurence Louër, 195-217. London: Hurst.

Halliday, Fred. 1988. "The Iranian Revolution: Uneven Development and Religious Populism.” In State and Ideology in the Middle East and Pakistan, edited by Fred Halliday, and Hamza Alavi, 31-63. London et al.: MacMillan Education.

Halliday, Fred. 2000. Nation and Religion in the Middle East. London: Saqi Books.

Haynes, Jeffrey, ed. 2016. Routledge Handbook of Religion and Politics. Abingdon: Routledge.

Hurd, Elizabeth Shakman. 2004. "The Political Authority of Secularism in International Relations." European Journal of International Relations 10, no. 2: 235-62.

Lacey, Robert, and Jonathan Benthall, eds. 2014. Introduction to GulfCharities and Islamic Philanthropy in the 'Age of Terror' and beyond, 1-23. Berlin: Gerlach Press.

Louër, Laurence. 2011. Transnational Shia Politics: Religious and Political Networks in the Gulf. London: Hurst.

Lowi, Miriam R. 2017. "Justice, Charity and the Common Good: In Search of Islam in Gulf PetroMonarchies." Middle East Journal 71, no. 4: 563-85.

Luhmann, Niklas. 2000. Die Religion der Gesellschaft. Frankfurt am Main: Suhrkamp.

Lynch, Cecelia 2014. "A neo-Weberian approach to religion in international politics. A NeoWeberian Approach to Studying Religion and Violence." Millenium - Journal of International Studies 43, no. 1: 273-90.

Mato Bouzas, Antía. 2017. "Territorialisation, ambivalence and the representational spaces in Gilgit-Baltistan.” Transcultural Studies 1: 197-223. 
Mato Bouzas, Antía. 2018. "From the Karakoram Mountains to the Gulf: Migration, Development and Religion in the Making of Transnational Spaces." ZMO Working Papers, no. 21. https://d-nb.info/1176721798/34, accessed March 26, 2021.

Matthiesen, Toby. 2013. Sectarian Gulf. Bahrain, Saudi Arabia, and the Arab Spring that wasn't. Stanford: Stanford University Press.

Morrison, Ian Anthony. 2013. "Rancière, religion and the political." Citizenship Studies 17, no. 6-7: 866-900.

Owen, Roger. 2000. State, Power and Politics in the Making of the Modern Middle East. London: Routledge.

Reetz, Dietrich. 2013. "Travelling Islam - Madrasa Graduates from India and Pakistan in the Malay Archipelago." ZMO Working Papers, no. 8. http://d-nb.info/1035516322/34, accessed March 26, 2021.

Rizvi, Sajjad. 2018. "The Making of a Marja': Sīstānī and Shi' i Religious Authority in the Contemporary Age." Sociology of Islam 6, no. 2: 165-89.

Schwarz, Tanya B., and Cecelia Lynch. 2016. "Religion in International Relations." Oxford Research Encyclopedia of Politics. https://doi.org/10.1093/acrefore/9780190228637. 013.122, accessed March 26, 2021.

Shaikh, Farzana. 2009. Making Sense of Pakistan. New York: Columbia University Press.

Sheikh, Mona Kanwal. 2015. "Sociotheology: The Significance of Religious Woldviews." In Nations under God. The Geopolitics of Faith in the Twentieth-First Century, edited by Luke M. Herrington, Alasdair McKay, and Jeffrey Haynes, 134-43. Bristol: E-International Relations Publishing.

Siddiqa, Ayesha. 2007. Military Inc.: Inside Pakistan's Military Economy. London: Pluto Press.

Skocpol, Theda. 1994. Social revolutions in the modern world. Cambridge et al.: Cambridge University Press.

Stöber, Georg. 2007. “Religious Identities Provoked: The Gilgit 'Textbook Controversy' and its Conflictual Context." Internationale Schulbuchforschung/International Textbook Research 29, no 4: 389-411. 
